\title{
Hydroelectric centrals' impact on territorial sustainability: analysis in southern Colombia
}

\begin{abstract}
This study evaluates sustainability in the Huila Department in southern Colombia following the construction of two hydroelectric plants. This evaluation is based on the Sepúlveda (2008) sustainability analysis model, which is especially suited to Latin American rural territories. The importance of this evaluation of sustainability in the Huila region stems from the environmental crisis that, according to various regional stakeholders, has been caused by the construction of the two hydroelectric plants. The results of this investigation indicate that the sustainability of the region is at risk because of these hydroelectric projects.
\end{abstract}

Keywords

Sustainability $\cdot$ hydroelectric sector $\cdot$ location factors $\cdot$ Huila $\bullet$ Colombia

(c) University of Warsaw - Faculty of Geography and Regional Studies

\author{
Duván Ramírez $\mathbb{C}^{1}$ \\ Luis Alfredo Muñoz Velasco $\mathbb{C}^{2}$ \\ ${ }^{1}$ Faculty of Accounting, Economic and Administrative \\ Sciences, University of Manizales, Manizales, Caldas, \\ Colombia \\ e-mail: merca2@umanizales.edu.co \\ ${ }^{2}$ Faculty of Economics and Administration, \\ Surcolombiana University, Neiva, Huila, Colombia \\ e-mail: luisalfredo.munoz@usco.edu.co \\ Received: 17 September 2019 \\ Accepted: 17 February 2020
}

Introduction

The word "spatial" is a territorial expression that reflects the space in which humans create and recreate their lives (Yory 2012). Occasionally, abrupt changes occur in this environment that aim to transform the topophilic relationship that exists between humans and their space, which lends credence to the notion that the impact of the game of substituting the characteristic nature of the human-territory relationship causes, not only to biodiversity, but also quality of life and human dignity.

One example of abrupt changes to the environment is the construction of two hydroelectric plants in Colombia: Betania and El Quimbo. The construction of Betania was authorized by the Colombian government in 1972 without an environmental impact analysis; it responded to the historical need to boost the economy in southern Colombia (Pulido 2014). Betania is considered to be the first multiple-purpose hydro-energy use project on the Magdalena, the most important river in Colombian. The construction of Betania aimed to increase both the coverage and continuity of energy services, as well generate employment in the Huila Department in southern Colombia. Construction began in 1981, and its operation was initiated in 1987.

Because of Betania's short lifetime due to excessive sedimentation, the El Quimbo hydroelectric plant was built 12 $\mathrm{km}$ away to safeguard regional hydroelectric operation. The construction of EI Quimbo began in 2010, and it initiated operations in 2015. Its construction was delayed due to authorization issues, since it was believed that it would produce a negative impact on the social, environmental, and economic levels present in the Huila Department at that time. In 2008, the Colombian government authorized its construction, as it was considered to be a project of national and international interest because of the potential to export energy from the operation of both plants. Therefore, both hydroelectric plants were built, with the help of investment and public-private interests. However, before their construction, the
Colombian government did not perform exhaustive assessments of the environmental impact that would be generated in Huila. Currently both plants face environmental problems. Figure 1 shows the map of the area over which Betania had direct, specific influence in 1986; and Figure 2 shows how this area changed up to 2017. Figure 3 shows the map of the area over which El Quimbo had direct, specific influence in 1986; and Figure 4 show how this area changed up to 2017.

As observed in Fig. 2 and 4, the presence of the Betania and El Quimbo dams has caused a mutation of the landscape, biodiversity, and the spatial setting. This has modified multiple territorial qualities, including geography, economy, and institutionalism, among others. These dams have generated various conflictive relationships between society, the State, and nature within Huila's territory, and affects over 15,000 hectares of land suitable for farming and pastoralism (Fig.1,3).

In the case of the El Quimbo dam (Fig. 4), the perception of change is made evident through the observation of the way in which governmental decisions have protected and promoted the patrimonial plundering and the displacement of collectives who are dedicated to the agricultural economy. The presence of the hydroelectric plants has not contributed to the well-being of the inhabitants of Huila, and lacks any authentic relationship between social cohesion and integral sustainability.

In 2013, the General Comptroller of the Republic of Colombia reviewed the 29 complaints presented, during 2013 and 2014, by affected citizens, non-governmental organizations, and in certain cases, academics, primarily from the Huila Department, relating to the problems generated by the creation of the El Quimbo and Betania dams. This clearly reflects the general malaise of the citizens, which has now been accompanied by the corporate and political leadership in Huila, as demonstrated by the actions of the General Comptroller of the Republic, as well as the various 


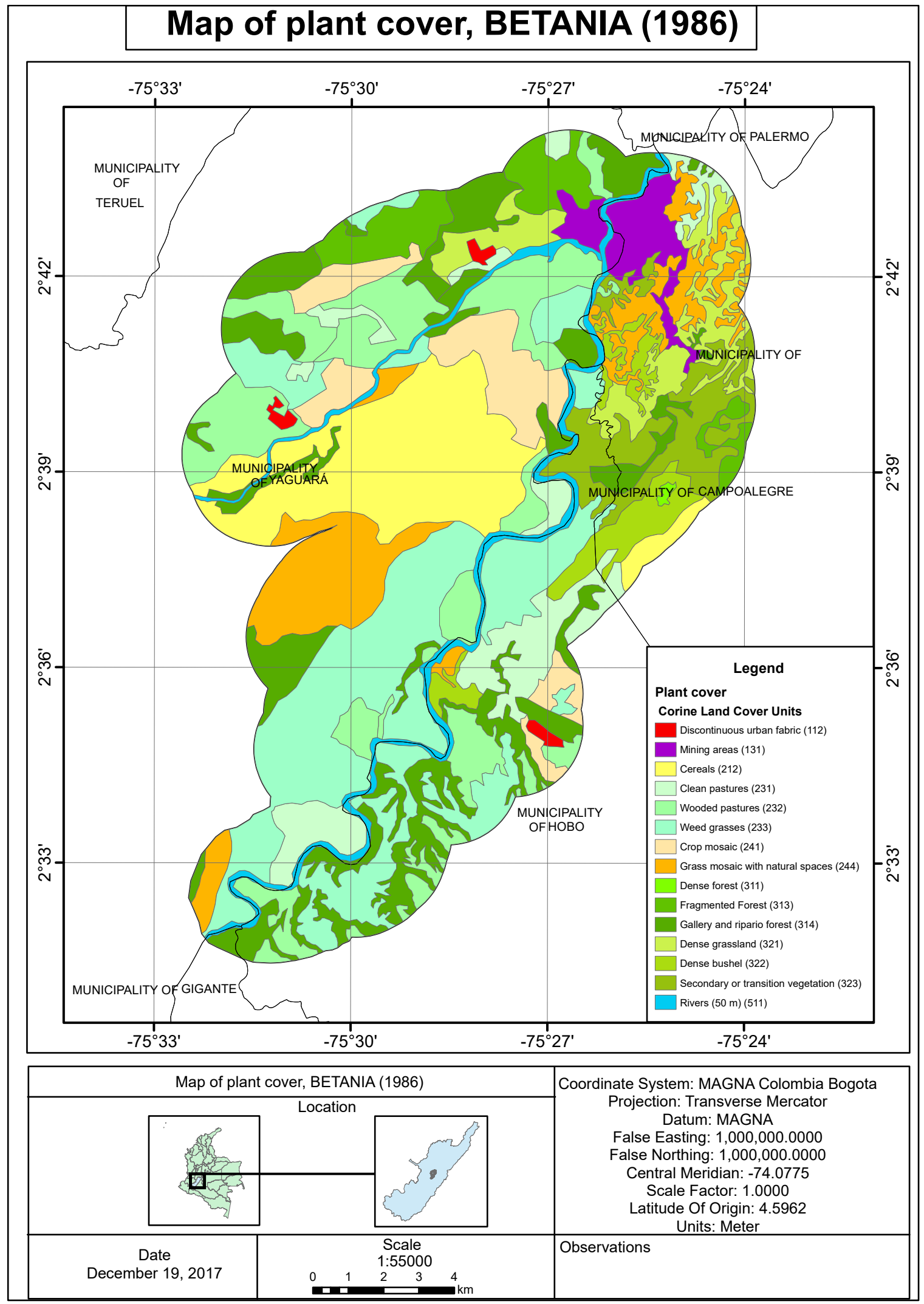

Figure 1. Map of the area over which Betania had direct, specific influence, 1986

Source: elaboration based on pictures taken by the Agustín Codazzi-Institute, Colombia, 1986 


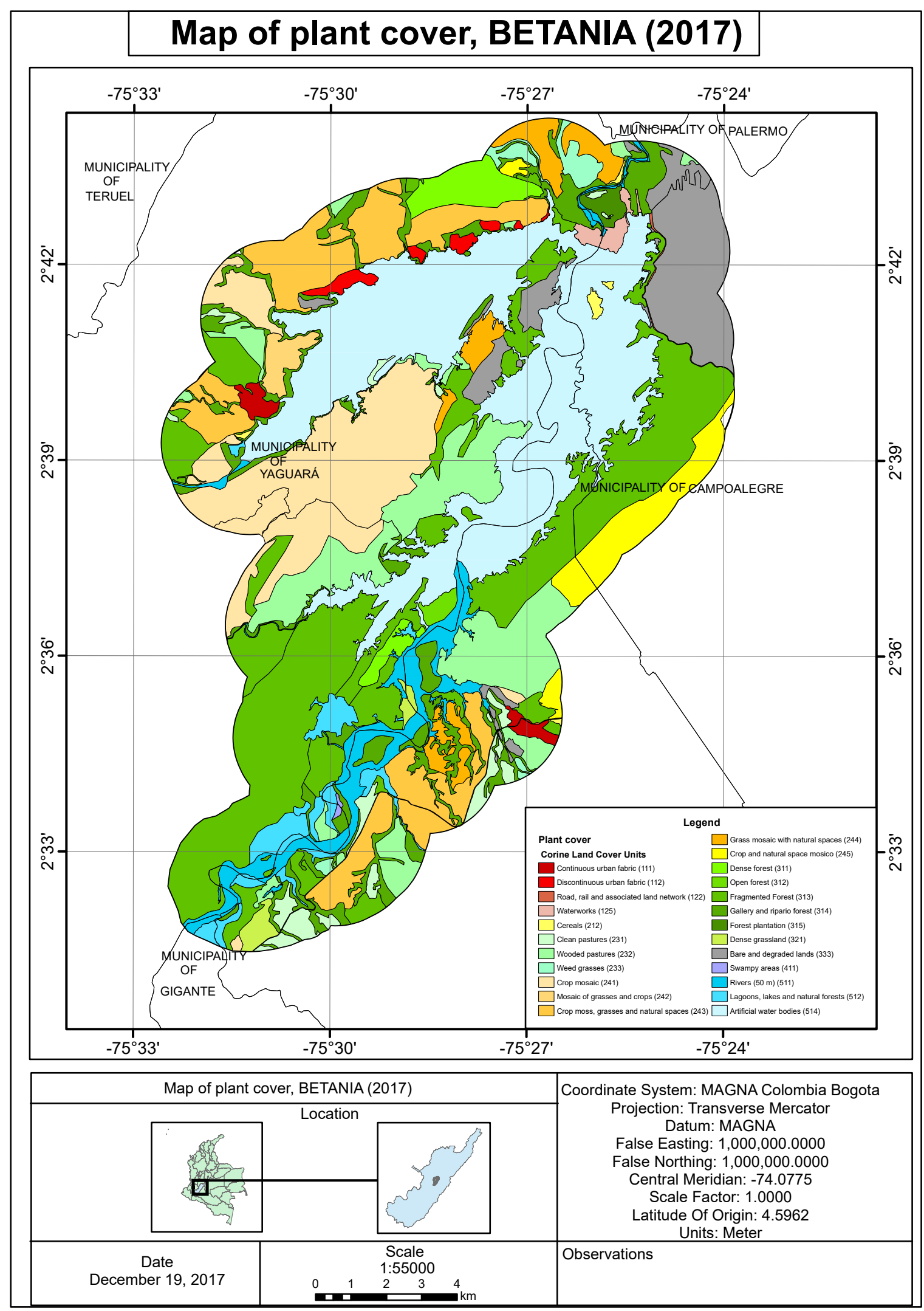

Figure 2. Map of the area over which Betania had direct, specific influence, 2017

Source: elaboration based on pictures obtained through RapidEye Satellite, 2017 


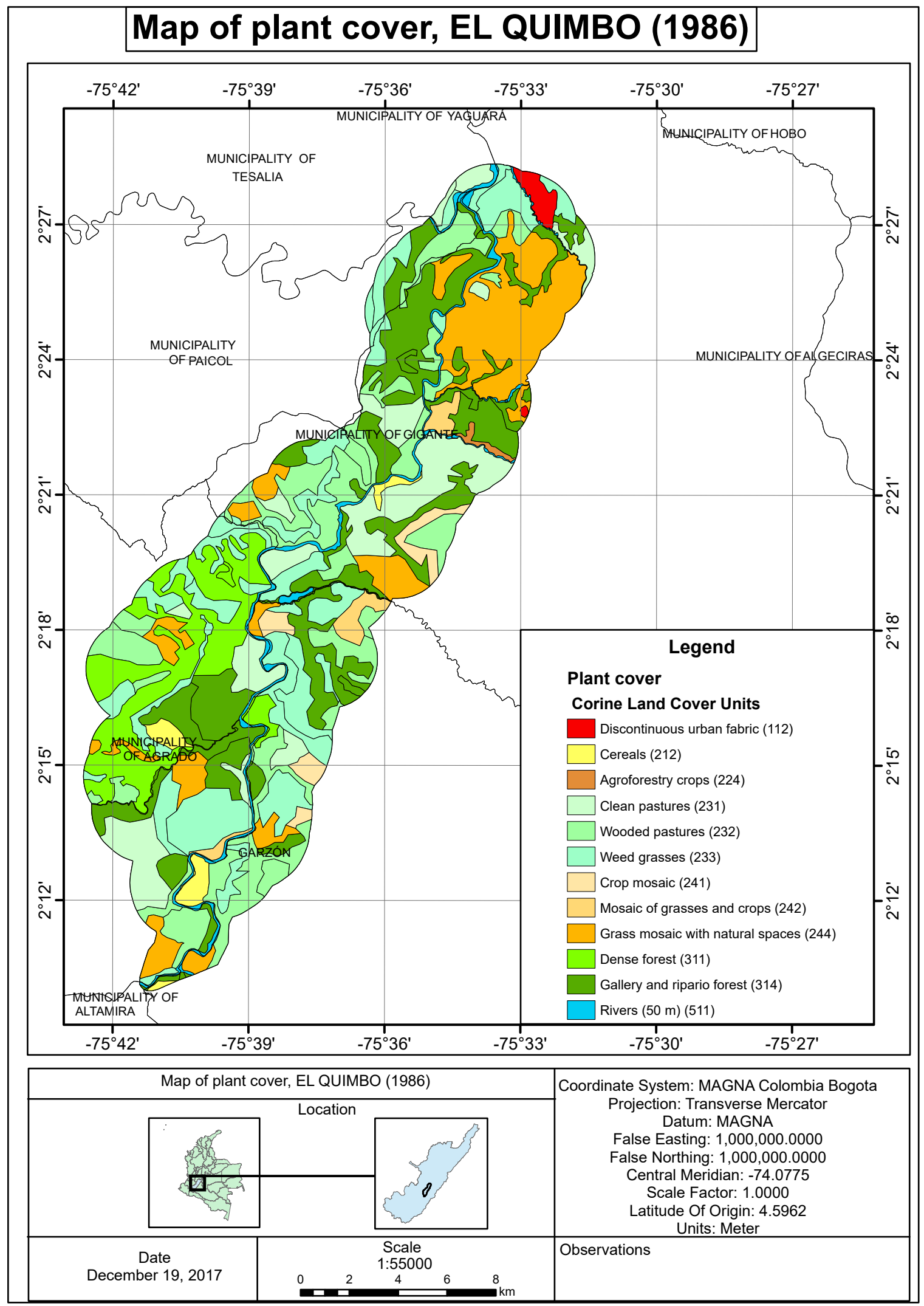

Figure 3. Map of the area over which El Quimbo had direct, specific influence, 1986

Source: elaboration based on pictures taken by the Agustín Codazzi-Institute, Colombia, 1986 


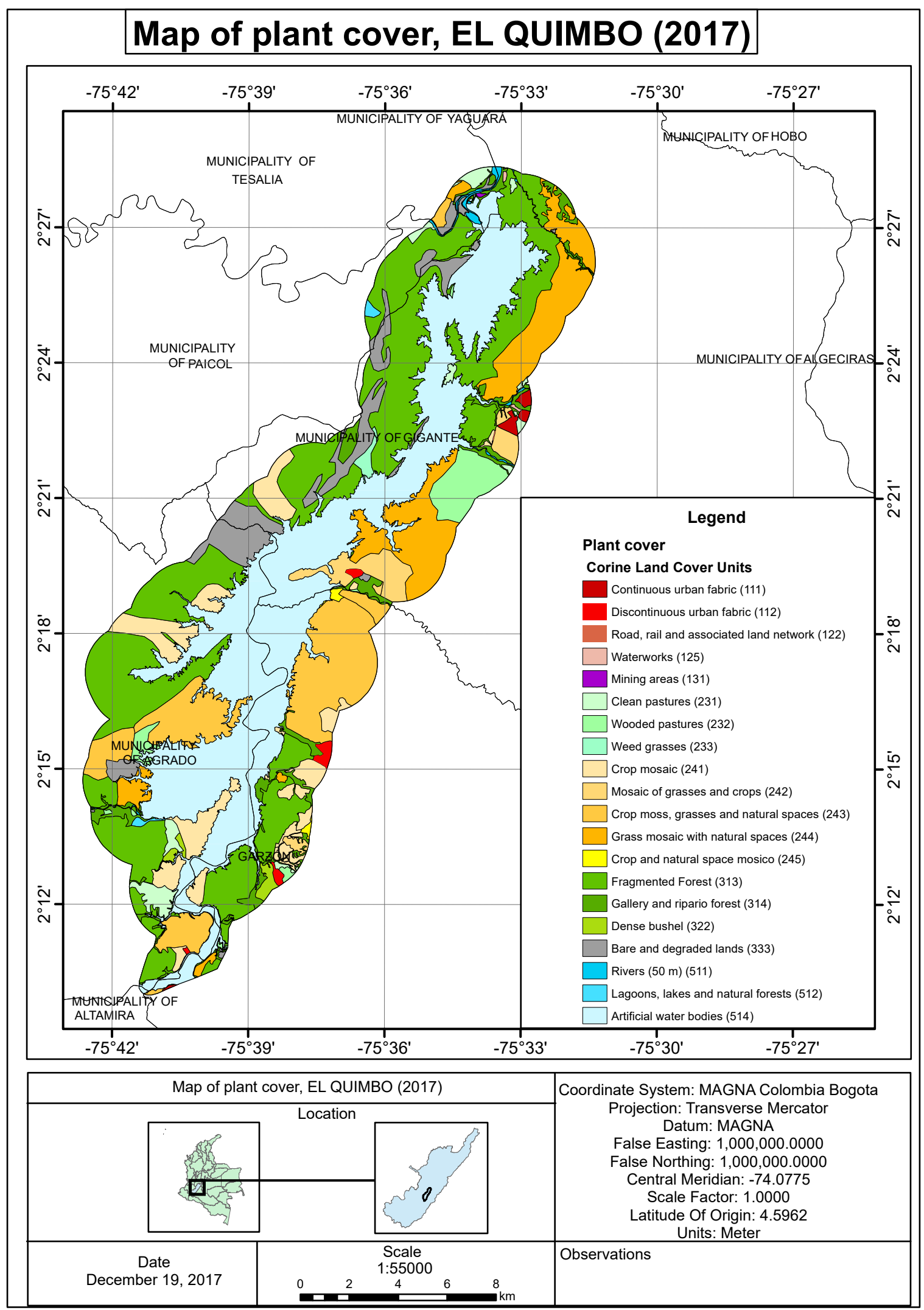

Figure 4. Map of the area over which El Quimbo had direct, specific influence, 2017

Source: elaboration based on pictures obtained through RapidEye Satellite, 2017 
environmental movements that have emerged in defense of water and territory. These movements also reject the central power's disregard for territorial sovereignty in favor of companies that, in the course of their accumulation of capital and territorial occupation, promote displacement and dispossession. This tendency creates displacement to the benefit of development and the victims of development (Dussán 2017), which clashes with the perception of those affected by the activities of the hydroelectric plants.

It should be added that the dynamics that result from these territorial economic processes require a developmentally sustainable relationship for social cohesion, because the link between economic processes and ecosystemic dynamics is vital, and references the environmental carrying capacity (Rees 1996) of the locales in which these processes occur. Thus, sustainable development implies that, as a condition, economic processes contribute to ecosystems in a way which, (1) conserves a certain number of natural resources and amount of environmental quality, (2) makes the intensity and permanency of the activity permit ecosystemic restitution in order to guarantee its current and future potential, and (3) guarantees the natural patrimony, biodiversity, and production of environmental services over time (Canal, Quiroga \& Rodríguez 2010). Consequently, in this study we test the hypothesis that the construction and operation of the Betania and El Quimbo hydroelectric plants has not had an effect on integrated sustainable development in the Huila territory.

\section{Methodology}

The methodological framework addressed in this study, and proposed by Sepúlveda (2008), develops a biogram in order to estimate the relative degree of sustainable development in Huila and its municipalities that confirms the area of direct local influence. These municipalities share a portion of their territory with the Betania and El Quimbo dams, and is affected by their operations. This methodology was chosen as it has been effective in the analysis of sustainability in various productive sectors in Latin America (Albuquerque, Giffoni \& Bagano 2018). Reis and Cândido (2012) recommend the use of Sepúlveda's (2008) model given its appropriateness for evaluating sustainability in rural Latin American territories.

Regarding the environmental situation of the territory under study, sustainable development must firstly be conceived of as a multidimensional, intertemporal, and spatial process, in which the concepts of sustainability, equity, competitively, and governability are created and recreated, dynamized, and become representative within the territorial system through environmental, social, economic, and politico-institutional dimensions.

The percentages of relative importance $(\beta)$ assigned to each dimension were as follows: $30 \%$ to environmental, $25 \%$ to social, $25 \%$ to economic, and $20 \%$ to political-institutional. These percentages resulted from a tendency analysis of the importance of the variables for each index dimension. Microsoft Excel for Mac was used for the empirical analysis to obtain the biogram and the tendency analysis for each Index Dimension (ID) for the integrated sustainable development evaluation. A total of 29 variables were identified for integrated sustainable development, and these were used to calculate each index dimension. These were affected by the relative importance percentages $(\beta)$, and allowed for the construction of a new indicator, which Sepúlveda (2008) recognizes as being the Integrated Sustainable Development Index (S3). S3 represents the general situation of the entire system, and its value may vary between zero and one. A value near one indicates that the system has superior developmental performance, while a value near zero indicates inferior developmental performance. Finally, the biogram forms part of the territory's environmental situation; it is defined by an image or web graphic, together with the tendency analysis.
Table 1. Biogram: Evaluation of the system in accordance with the index range

\begin{tabular}{|c|c|}
\hline Index range & State of sustainable development \\
\hline$>0.8<=1.0$ & Optimum \\
\hline$>0.6<=0.8$ & Stable \\
\hline$>0.4<=0.6$ & Unstable \\
\hline$>0.2<=0.4$ & Critical \\
\hline$>0.0<=0.2$ & Collapse \\
\hline
\end{tabular}

Source: Sepúlveda, 2008, p.28.

This research shows, quantitatively, the state of sustainable development of the Unit Analyzed (UA). For the purposes of this research the Huila Department has been subdivided into: (1) the El Hobo, Campoalegre, Gigante, and Yaguará municipalities, which are influenced by Betania; and (2) the Agrado, Altamira, Garzón, Gigante, Paicol, and Tesalia municipalities, which are influenced by El Quimbo.

The biogram reveals the degree of UA development and the possible imbalances between the various dimensions and levels of existing conflict, as indicated in Table 1.

The biogram shows the state of the system in accordance with index range connected with a specific definition, which is the field of political action determined in order to intervene promptly to correct any imbalances present in the UA. As a result, the tendency analysis shows the behavior of each dimension over time; by which future behavior may be predicted or anticipated. Despite the usability of the method, it may appear biased due to the difficult process of obtaining data, especially from a single source, such as the government of the Huila Department or the National Statistics Department. It was important to access several sources and databases that have high levels of credibility and reliability (Nardo et al. 2005).

\section{Process of data collection}

Considering that the biogram technique exhibits situational behavior, while the tendency analysis may predict future behavior with past information, the analysis is included here as a tool for the analysis of the average rate of growth of the state of sustainable development in the $\mathrm{Xt}$ and $\mathrm{Xt}+\mathrm{n}$ periods (or the geometric mean). It should be noted that this procedure permits the introduction of statistical tools that contribute to the analysis, and so the calculation of the geometric average was carried out using the following formula:

$$
g=\left(\frac{X t+n}{X t}\right)^{\frac{1}{n}}-1
$$

Where: $\mathrm{Xt}+\mathrm{n}$ is the value of the final year, and $\mathrm{Xt}$ is the value of the first year.

However, the selection of variables falls within the relevance criteria as mediated by institutional credibility; objectivity in the selection of useful data for indicator construction; availability, understood as access; and reliability, because it is open to the public (United Nations 2007). Once the variables involved in the creation of the index dimensions has been selected, database construction is required in the areas of direct local influence and direct specific influence of the hydroelectric processes involved in the Betania and El Quimbo plants. However, for a number of 
Table 2. Variables for each dimension

\begin{tabular}{|c|c|c|c|}
\hline \multicolumn{2}{|c|}{ DIMENSIONS } & INSTITUTIONAL & ENVIRONMENTAL \\
\hline ECONOMIC & SOCIAL & $\begin{array}{c}\text { Departmental electoral } \\
\text { participation percentage }\end{array}$ & Residential gas consumption \\
\hline Savings capacity & PET percentage & Departmental electoral abstention & $\begin{array}{c}\text { Residential energy } \\
\text { consumption }\end{array}$ \\
\hline $\begin{array}{c}\text { Income per capita } \\
\text { Fiscal performance index }\end{array}$ & $\begin{array}{c}\text { Reason for economic } \\
\text { dependence }\end{array}$ & Forced displacement or expulsion & CO2 emission intensity \\
\hline $\begin{array}{c}\text { Reliance on transfers and } \\
\text { royalties }\end{array}$ & Aging index & Homicides & Demographic density \\
\hline Magnitude of investment & Affiliation with subsidy system & Investment per capita & Rural index \\
\hline $\begin{array}{c}\text { Coefficient of variation per } \\
\text { capita }\end{array}$ & $\begin{array}{c}\text { Percentage of subsidy system } \\
\text { coverage }\end{array}$ & & \\
\hline Agribusiness credits & Mortality rate & & \\
\hline $\begin{array}{c}\text { Agricultural GDP at constant } \\
\text { prices (2005) }\end{array}$ & Uninsured poor population & & \\
\hline
\end{tabular}

Sources: authors' own elaboration

years there was a dearth of data, so this period was estimated using the rolling average technique (given the nature of the variable), so the period of analysis was, 1998 as the first year, and 2015 as the last year. This continuity of data obtained over time permits the statistical validation of the results.

Table 2 presents nine variables selected from the economic dimension, nine others from the social dimension, six from the political-institutional dimension, and five from the environmental dimension.

The environmental dimension encompasses complementary concepts that are associated with social and territorial cohesion (Table 2), understood as the construction of equitable societies that have a sense of belonging and spatial integration (Echeverri \& Ribero 2002). This definition presents variables associated with consumption and the environment, since modern societies measure well-being based on the purchasing power of goods and technologies and whose use entails energy consumption, which in turn depends on the population levels and the degree of rurality.

Finally, the availability and the access to data, and/or estimation thereof, were embrace as the selection criteria. Furthermore, these variables were believed to incorporate a relative significance value in territorial dynamics.

\section{Process of analysis}

Once the index dimensions were selected and the negative (0) or positive (1) relationship of the indicator defined, the observed values was chosen as the methodology, then the calculation of each variable's maximums and minimums was performed. Subsequently, the standardized relativization function was calculated by multiplying the negative variables by negative one, thus allowing the use of positive relationships between the variable and development. The relativization functions correspond to both positive and negative relationships: (1) $f x=(X-m) /(M-$ $m) ;(2) f x=(X-M) /(m-M)$, where $f x$ is the Relativization function, $X$ is the value of the variable within a determined period, $M$ is the maximum value of the variable within a determined period, and $m$ is the minimum value of the variable within a determined period. The sustainable development index was calculated for each dimension, once the dimension data was "relativized" (by averaging the indicators of the previously standardized dimension), in order that values between zero and one are chosen, and by following the formula:

$S d=\frac{1}{n d} \sum_{i=1}^{n d} I d i$

where $\mathrm{Sd}$ is the sustainable dimensions, $\mathrm{Nd}$ is the $\mathrm{n}$ indicators, and Idi is the indicator that reflects the $D$ dimension.

The Integrated Sustainable Development Index (S3) was obtained by the aggregation of the weight of each dimension in accordance with the percentage of importance $(\beta D)$, and following the formula:

$$
S 3=\sum_{1}^{M}\left(\frac{\beta D}{100}\right) S
$$

where S3 is the Integrated Sustainable Development Index, M is the Maximum Value of the Variable within a Determined Period, $\beta D$ is the Percentage of Importance of the D Dimension, and $S$ is the Sustainable Dimension.

\section{Results}

The multidimensional and intertemporal perspective of sustainable territory development proposed by Sepúlveda (2008) includes economic, social, politico-institutional, environmental dimensions, and the S3 presented in Table 3, together with the results obtained for the Huila department, during the period of 1998-2015. 
MISCELLANEA GEOGRAPHICA - REGIONAL STUDIES ON DEVELOPMENT

Vol. 24 • No. 2 - 2020 • pp. 73-84 • ISSN: 2084-6118 • DOI: 10.2478/mgrsd-2020-0010

Table 3. Distribution of sustainable development, 1998-2015

\begin{tabular}{|c|c|c|c|c|c|c|}
\hline Year & $\begin{array}{l}\text { Economic } \\
\text { dimension } \\
\text { index (SD) }\end{array}$ & $\begin{array}{c}\text { Social } \\
\text { dimension } \\
\text { index (SD) }\end{array}$ & $\begin{array}{c}\text { Index } \\
\text { institutional } \\
\text { dimension (SD) }\end{array}$ & $\begin{array}{l}\text { Environmental } \\
\text { dimension index } \\
\text { (SD) }\end{array}$ & $\begin{array}{l}\text { Integrated index } \\
\text { of sustainable } \\
\text { development (S3) }\end{array}$ & $\begin{array}{l}\text { System status } \\
\text { according to (S3) }\end{array}$ \\
\hline 1998 & 0.229 & 0.340 & 0.253 & 0.755 & 0.419 & \multirow{18}{*}{$\begin{array}{l}\text { The system in } \\
\text { Huila during the } \\
\text { period } 1998 \text { to } \\
2015 \text {, was highly } \\
\text { unstable }\end{array}$} \\
\hline 1999 & 0.320 & 0.429 & 0.434 & 0.652 & 0.470 & \\
\hline 2000 & 0.373 & 0.408 & 0.571 & 0.554 & 0.476 & \\
\hline 2001 & 0.498 & 0.376 & 0.509 & 0.628 & 0.509 & \\
\hline 2002 & 0.453 & 0.390 & 0.407 & 0.581 & 0.467 & \\
\hline 2003 & 0.443 & 0.407 & 0.358 & 0.539 & 0.446 & \\
\hline 2004 & 0.419 & 0.567 & 0.422 & 0.477 & 0.474 & \\
\hline 2005 & 0.749 & 0.472 & 0.507 & 0.449 & 0.541 & \\
\hline 2006 & 0.643 & 0.465 & 0.382 & 0.414 & 0.477 & \\
\hline 2007 & 0.654 & 0.470 & 0.456 & 0.394 & 0.490 & \\
\hline 2008 & 0.645 & 0.538 & 0.474 & 0.375 & 0.503 & \\
\hline 2009 & 0.684 & 0.550 & 0.659 & 0.350 & 0.545 & \\
\hline 2010 & 0.776 & 0.556 & 0.715 & 0.355 & 0.582 & \\
\hline 2011 & 0.701 & 0.635 & 0.765 & 0.349 & 0.592 & \\
\hline 2012 & 0.756 & 0.673 & 0.798 & 0.273 & 0.599 & \\
\hline 2013 & 0.578 & 0.693 & 0.730 & 0.365 & 0.573 & \\
\hline 2014 & 0.665 & 0.668 & 0.704 & 0.299 & 0.564 & \\
\hline 2015 & 0.632 & 0.573 & 0.740 & 0.407 & 0.571 & \\
\hline
\end{tabular}

Index range: Optimum $>0.8<=1.0$; Stable $>0.6<=0.8$; Unstable $>0.4<=0.6$; Critical $>0.2<=0.4$; Collapse $>0.0<=0.2$ Source: own calculations, according to the methodology of Sepúlveda (2008).

In an initial interpretative approach to the model results, it was determined that the level of sustainable territorial development remained within the $>0.4<0.6$ range. The average rate of integrated sustainable development growth for the 1998-2015 period was $1.73 \%$. While this S3 does denote an improvement in index and departmental conditions, it remains weak, and indicates instability. However, when intertemporal analysis was performed for the same period using this tool, it was found that performance in the environmental dimension had deteriorated by $3.37 \%$; with the average growth rate for the previous year (2014) being $-5.01 \%$, this placed it in a critical state. The social dimension changed from a critical state to an unstable state, and the economic and political-institutional dimensions changed from critical to stable.

The biogram illustrates the index behavior for each dimension during the period under study, and indicates, based on the shaded area, the years in which the index performed best. In accordance with this statement, 1998-2000 reflects the worst performance in the economic dimension, with the departmental total below the median (0.5, unstable). Lira and Quiroga (2009), as well as, Boisier (1980) tell us that, when taken in the context of regional analysis, with limited information for indicator generation, including economic analysis tools; this demonstrates the low competitive capacity of the UA.
The economic dimension, during the period 1998-2015

The social dimension during the period 1998-2015 presented different states of equity, which was reflected in an index that passed from a critical state (1998) to an unstable state (1999-2000), and then returned to a critical state for the following two years. While the indicator improved during the 2003-2010 period, it did not emerge from the instability category, despite the fact that from 2011-2014 it had overtaken the average and had achieved a stable state. When these results are compared to social indicators such as multidimensional poverty, monetary poverty, and GINI, it reinforces the observation of the UA's state of inequality (see Fig. 5).

The politico-institutional dimension shows adequate performance from 2009-2015, which is in contrast to the presence of water and territory defense institutions and organizations present in the region, who made a constant effort to rescue territorial governance and governability that had been affected by decisions at the national level - the national level having imposed the development of extractive activities that only benefitted foreign capital.

The environmental dimension had its worst performance recorded from 2007 to 2014, in which it maintained critical status during the period of the El Quimbo hydroelectric plant's construction. Along with this, there were certain effects within the 
Economic dimension Index(SD)

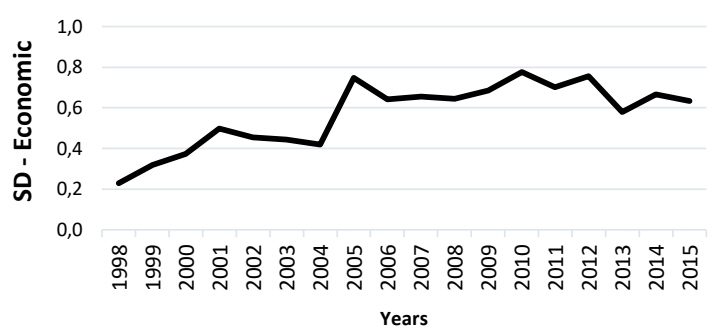

Institutional Dimension Index - SD

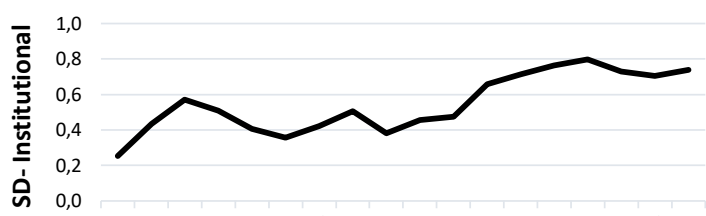

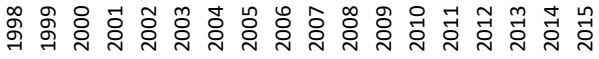

Years

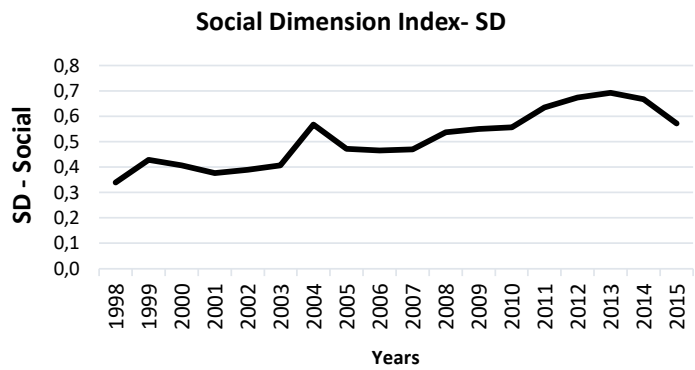

Environmental dimension Index-SD

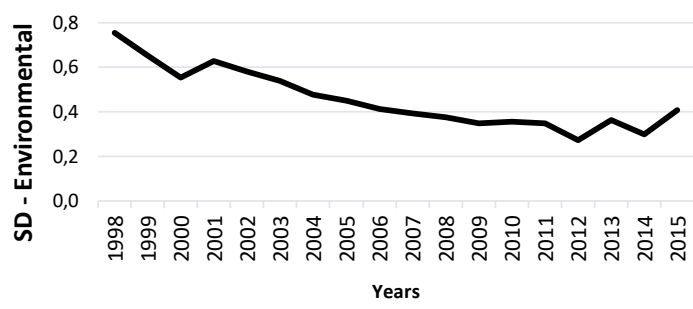

Figure 5. Distribution of the economic, social, politic-institutional and environmental dimensions, 1998-2015 Source: Own elaboration based on Sepúlveda (2008)

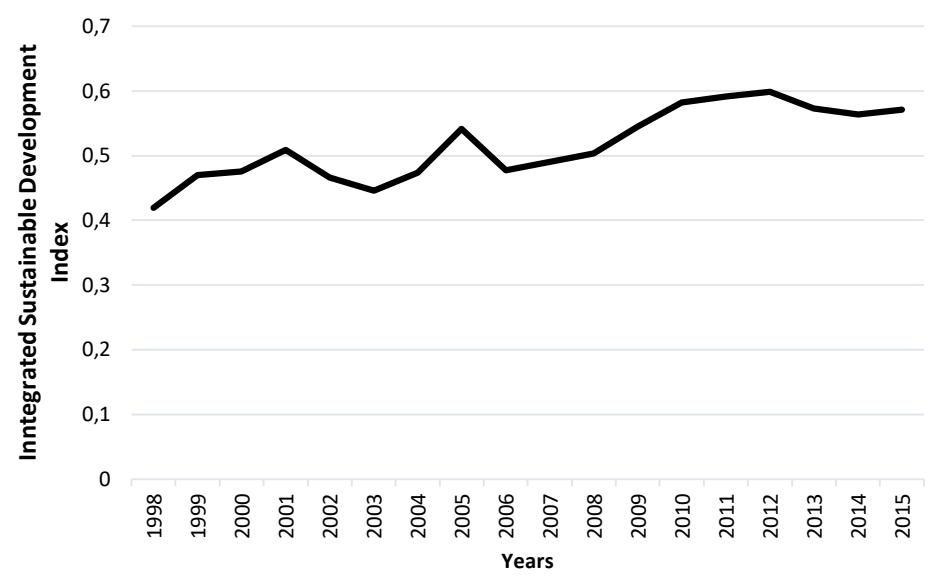

Figure 6. Integrated Sustainable Development Index, 1998-2015

territory that even influenced the operation of certain economic activities, including pisciculture, which was present in the Betania hydroelectric plants. This was as a consequence of changes in the quantity and quality of the Magdalena River's water, which is the principal tributary for both reservoirs. In 2015 and 20042006, however, the indicator was below average, and passed from critical to a highly unstable state, a fact that requires the serious consideration of public policy for territorial defense, as one's territory is a vital space for well-being (see Fig. 5)

In Fig. 6, it is possible to see that the tendency analysis reveals that the $S 3$, with a standard deviation or volatility of $( \pm)$ 0.055 , indicates a tendency to fall to 0.44 , which would move the Huila Department from an unstable to a critical situation in terms of its level of sustainable territorial development. This may then indicate that the presence of the Betania and El Quimbo hydroelectric plants has not contributed to the maintenance of a sustainable territory, as the index data for the environmental dimension for 2007-2014 presents a critical evaluation, with a variability of $( \pm) 0.13$, and an increasing trend.
The dominant characteristic during the 1998-2015 period, both in those municipalities that share a portion of their territory with the reservoir and those that form part of the area of the Betania or the El Quimbo hydroelectric plants' direct local influence, is a state of instability in sustainable development over most of the period analyzed; with some in critical states, primarily at the beginning of the above-mentioned period.

In the case of the municipalities in the areas of direct local influence of Betania, the sustainable development index was in an unstable state, and while the Campoalegre and Yaguará municipalities presented a tendency toward stability in the last year of the period examined, analysis of the harmonic mean (considered to be more precise than the arithmetic or geometric mean) reveals that the sustainable development index was 0.50 for Campoalegre and Gigante, and 0.51 for Yaguará and EI Hobo: ratios that put the system in an unstable state (see Fig. 7).

Analysis by dimension, by way of the harmonic mean, concludes that during the observation period all of the municipalities in the area of direct local influence of the Betania 
MISCELLANEA GEOGRAPHICA - REGIONAL STUDIES ON DEVELOPMENT

Vol. 24 • No. 2 • 2020 • pp. 73-84 • ISSN: 2084-6118 • DOI: 10.2478/mgrsd-2020-0010

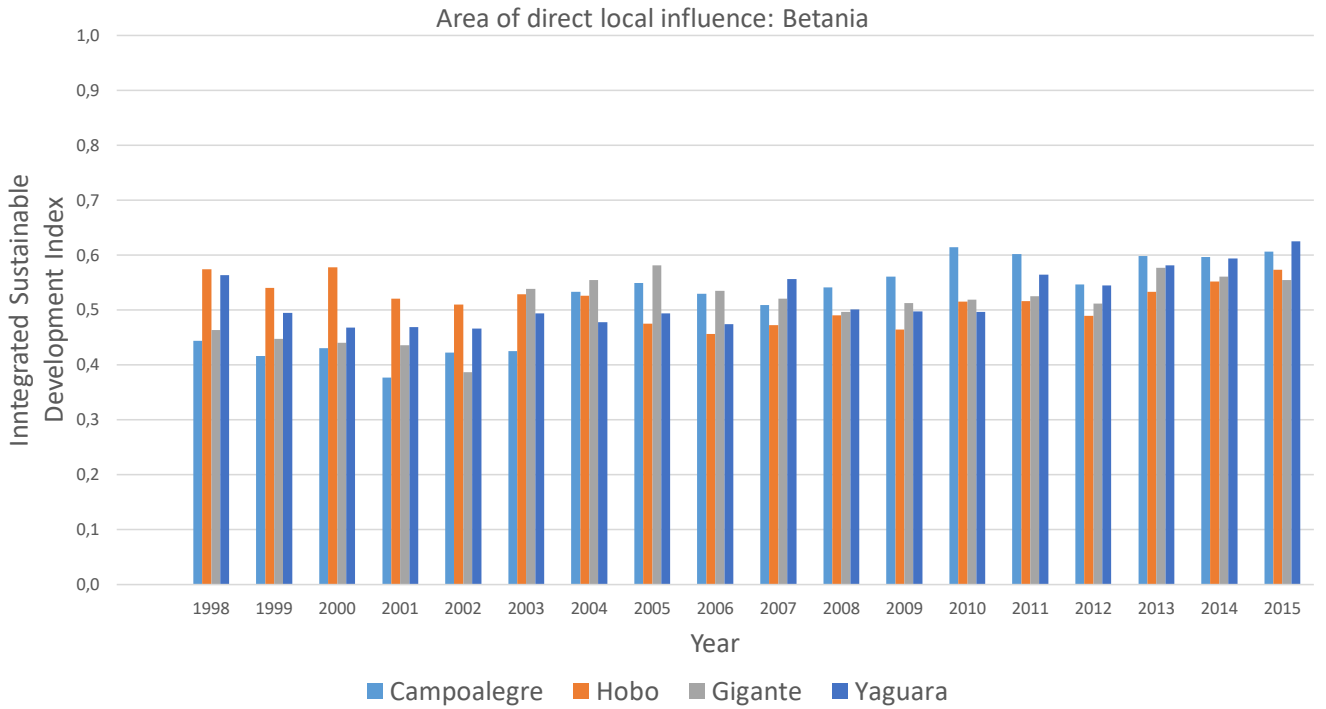

Figure 7. Biogram application in municipalities within the area of direct local influence of Betania Source: Own elaboration based on Sepúlveda (2008)

hydroelectric plant were in an unstable state, with an average that oscillated between 0.43 and 0.55 for the economic, social, institutional, and environmental dimensions.

El Hobo was the exception, as its mean for the environmental dimension was 0.37 , which placed it in critical state. In the interim, the municipalities that conform to the area of direct local influence of the El Quimbo hydroelectric plant presented a harmonic mean for the sustainable development index that oscillated between 0.47 , in the case of Tesalia, and 0.55 in the case of Garzón, such that the unstable status remained unchanged during the period of the study (see Table 4). Likewise, the integrated sustainable development index and analysis, by dimension and locality, used the harmonic mean as a statistical tool for the Agrado, Altamira, Garzón, and Paicol municipalities (see Table 4.).

In accordance with the methodology proposed by Sepúlveda (2008), the economic dimension oscillated between 0.42 and 0.53; excepting Tesalia, whose harmonic mean in this dimension was 0.39 , which constitutes a critical state. The municipality of Garzón has a critical influence on the political-institutional, social-economic, and environmental dimensions.

\section{Discussion}

This investigation's hypothesis was that the construction and operation of the Betania and El Quimbo hydroelectric plants had not had an effect on the S3 for the Huila territory. In order to refute or confirm the proposed hypothesis, it should be noted that the Betania hydroelectric plant began operation in 1987, the El Quimbo hydroelectric plant in 2015, and that the S3 for the Huila Department puts it squarely in a highly unstable state.

A comparison of the variables in their dimensional components confirmed that, during most of the observation period, the variables moved between critical states and unstable states, coinciding with the operation of the Betania hydroelectric plant, and the construction and subsequent operation of the El Quimbo hydroelectric plant. This, in addition to the biotic and physical analyses performed during the course of the investigation, showed a change not only in the landscape, which altered the spatial conditions and as such territorial development, as seen in Fig. 1 and 3 (showing a before and after images of the Betania and El Quimbo hydroelectric plants), but rather in the environmental development of the Huila Department. This is reinforced when the analysis is performed based on those municipalities that comprise the direct local and direct specific areas affected by these mega infrastructure projects from the hydroelectric sector.

In the case of the municipalities in the area of Betania's influence, the S3 index reflects a state of instability, and while in the final year of the period analyzed the Campoalegre and Yaguará municipalities presented a tendency toward stability, an analysis of the harmonic mean (which is more precise than the arithmetic or geometric means) reveals that the sustainable development index was 0.50 for Campoalegre and Gigante, and 0.51 for Yaguará and El Hobo, which classifies them as unstable in terms of territorial sustainability. Similarly, considering the analysis by dimension by way of the harmonic mean, it was concluded that, during the period of observation, all of the municipalities in the area of direct local influence of Betania were in unstable states, with averages that oscillated between 0.43 and 0.55 in the economic, social, institutional, and environmental dimensions; excepting El Hobo, which had an environmental dimension average of 0.37 , which places it in a critical state. Meanwhile, those municipalities that constitute the area of direct local influence of El Quimbo presented, during the period of study, a harmonic mean for the sustainable development index that oscillated between 0.47 , in the case of Tesalia, and 0.55 for Garzón, which represents an unstable evaluation.

However, the construction of the Betania dam did control the flow of the river, increased tourism, improved fish farming and irrigation for agricultural activities, and caused the generation of $510 \mathrm{MW}$ of power for 10 departments in Colombia; and the El Quimbo construction contributed 400 MWof power, equivalent to $4 \%$ of the total demand for electricity in Colombia.

It is important to consider that this study has limitations, in that the method employed the maximum and minimum observed values for each variable. Therefore, the selection of variables was based on the criterion of representativeness and information availability for the unit of analysis. In fact, the period between 1998 and 2015 was studied because it lacked reliable data that would allow for an analysis from the outset of the dam's operation.

In conclusion, it can be affirmed that the impact of the Betania and El Quimbo hydroelectric plants on the region has been mainly negative, since their presence in the territory has 
Table 4. Distribution of the Integrated Sustainable Development Index (S3), by areas under direct local influence of El Quimbo, 1998-2015

\begin{tabular}{|c|c|c|c|c|c|c|}
\hline \multicolumn{7}{|c|}{ Area of Direct Local Influence: EI Quimbo } \\
\hline Year & Agrado & Altamira & Garzón & Gigante & Paicol & Tesalia \\
\hline 1998 & 0.458 & 0.486 & 0.464 & 0.463 & 0.461 & 0.503 \\
\hline 1999 & 0.440 & 0.476 & 0.481 & 0.447 & 0.426 & 0.470 \\
\hline 2000 & 0.428 & 0.467 & 0.455 & 0.440 & 0.359 & 0.377 \\
\hline 2001 & 0.432 & 0.442 & 0.451 & 0.436 & 0.356 & 0.408 \\
\hline 2002 & 0.381 & 0.429 & 0.450 & 0.387 & 0.354 & 0.408 \\
\hline 2003 & 0.444 & 0.421 & 0.533 & 0.539 & 0.433 & 0.463 \\
\hline 2004 & 0.532 & 0.491 & 0.568 & 0.555 & 0.553 & 0.449 \\
\hline 2005 & 0.492 & 0.425 & 0.632 & 0.582 & 0.516 & 0.412 \\
\hline 2006 & 0.517 & 0.461 & 0.656 & 0.535 & 0.540 & 0.410 \\
\hline 2007 & 0.509 & 0.475 & 0.574 & 0.521 & 0.528 & 0.507 \\
\hline 2008 & 0.511 & 0.516 & 0.546 & 0.496 & 0.522 & 0.492 \\
\hline 2009 & 0.524 & 0.537 & 0.567 & 0.512 & 0.548 & 0.501 \\
\hline 2010 & 0.581 & 0.569 & 0.593 & 0.519 & 0.580 & 0.522 \\
\hline 2011 & 0.606 & 0.565 & 0.631 & 0.525 & 0.592 & 0.578 \\
\hline 2012 & 0.619 & 0.573 & 0.594 & 0.512 & 0.547 & 0.565 \\
\hline 2013 & 0.640 & 0.641 & 0.646 & 0.577 & 0.615 & 0.544 \\
\hline 2014 & 0.578 & 0.615 & 0.648 & 0.561 & 0.634 & 0.558 \\
\hline 2015 & 0.606 & 0.675 & 0.664 & 0.555 & 0.697 & 0.570 \\
\hline Harmonic mean & 0.506 & 0.505 & 0.554 & 0.503 & 0.495 & 0.477 \\
\hline
\end{tabular}

Index range (S3): Optimum $>0.8<=1.0$; Stable $>0.6<=0.8$; Unstable $>0.4<=0.6$; Critical $>0.2<=0.4$; Collapse $>0.0<=0.2$ Source: own elaboration, according to Sepúlveda (2008).

not contributed to improvements in economic conditions or social welfare, and has had negative effects on the biological systems in the area. However, thanks to the identification of the negative impact of the dams, the population of Huila is more aware of the environmental impacts that the construction of hydroelectric plants brings. Their presence has caused the organization of the community in defense of water and territory, and has forced the government to adopt a culture in defense of regional resources. There have also been legal confrontations between hydroelectric owners, the affected populations, and environmental groups.

ORCID

Duvan Ramirez (ID https://orcid.org/0000-0002-6556-5104 Luis Alfredo Muñoz Velasco (1) https://orcid.org/0000-0003-4112-8994

\section{References}

Albuquerque, G, Giffoni, MA \& Bagano, MDS 2018. 'Sustentabilidade de agroecossistemas de produção familiar: uma avaliação com uso de indicadores em perímetros públicos de irrigação do norte da Bahia, ['Sustainability of family production agroecosystems: an assessment using indicators in public irrigation perimeters in northern Bahia'], Cadernos de Agroecologia, vol 13, no. 1, pp. 1-7.

Boisier, S 1980, 'Técnicas de análisis regional con información limitada' ['Regional analysis techniques with limited information'], Cuaderno ILPES, vol. II (27). Pág. 7

Canal, F, Quiroga, R, Rodriguez, Y, Stockins, P \& Nájera, M 2010, 'Tendiendo puentes entre el desarrollo sostenible y la cohesión social' ['Extending bridges between sustainable development and cohesion'] in Cohesión social en América Latina: una revisión de conceptos, marcos de referencia e indicadores, eds Naciones Unidas, Santiago de Chile, pp. 109-140.

Contralorìa General 2014, Seguimiento a denuncias ciudadanas para exigir el cumplimiento de obligaciones ambientales en la actual construcciòn de hidroeléctricas 2013 [Monitoring citizen resports to demand compliance with environmental obligations in the current construction of hydrolectric plants 2013], República de Colombia, ANLA.

Dussán, MA 2017, El Quimbo: extractivismo, despojo, ecocidio y resistencia [Extractivism, dispossession, ecocide, and resistance], Planeta Paz, Bogotá. 
Echeverri, R \& Ribero, MP 2002. Nueva ruralidad: Visiòn del territorio en Amèrica Latina y el Caribe. ['New rurality: Vision of the territory in Latin America and the Caribbean. San Jose'], Costa Rica: IICA, CIDER y la Corporaciòn Latinoamericana Misiòn Rural.

Lira, L \& Quiroga, B 2009, Técnicas de análisis regional [Regional analysis techniques], Instituto Latinoamericano y del Caribe de Planificación Económica y social (ILPES), Dirección de Gestión del Desarrollo Local y Regional, Santiago de Chile.

Nardo, M, Saisana, M, Saltelli, A, Tarantola, S, Hoftman, A \& Giovannini, E 2005, Handbook on constructing composite indicators.: Methodology and user guide, OECD statistics working paper, OECD, Paris.

Pulido, A 2014, Susurros del Magdalena-Los impactos de los megaproyectos en el desplazamiento forzado ['Magdalena's Whispers-The impacts of megaprojects on forced displacement'], Bilbao, Vizcaya, Paìs Vasco-España: Comisiòn de Ayuda al Refugiado en Euskadi. ['Commission for Aid to Refugees in the Basque Country']

Rees, WE 1996, 'La huella ecològica: Poblaciòn y riquezaIndicadores territoriales de sustentabilidad' ['Ecological footprint: Population and wealth-territorial indicators of sustainability'], Population and environment: A Journal of interdisciplinary studies, vol. 17, no. 2, pp. 27-41.

Reis, LMM \& Cândido, GA 2012, Sustentabilidade dos agroecossistemas intensivos de bananeira de IpanguaçuRN [Sustainability of Ipanguacu banana-intensive agroecosystems- RN], HOLOS, vol. 6, 28-42.

Sepúlveda, SS 2008, Metodología para estimar el nivel de desarrollo sostenible de territorios [Methodology to estimate the level of sutainable territorial development], IICA, San José, Costa Rica.

United Nations 2007, Indicators of sustainable development: Guidelines and methodologies, United Nations, New York, NY.

Yory, CM 2012, El desarrollo territorial integrado [Integrated Territorial Competitiveness], Universidad Piloto de Colombia, Bogotá. 